\title{
PHENYLPYRUVIC OLIGOPHRENIA. REPORT OF A CASE IN AN INFANT WITH QUANTITATIVE CHEMICAL STUDIES OF THE URINE
}

\author{
By MARGARET DANN, ELEANOR MARPLES, AND SAMUEL Z. LEVINE \\ (From the New York Hospital, and the Department of Pediatrics, Cornell University \\ Medical College, New York City)
}

(Received for publication July 31, 1942)

The object of this study is to present quantitative determinations of phenylalanine, tyrosine, and some of their derivatives, excreted by a two-yearold boy with clinical and urinary findings diagnostic of the rare condition known as phenylpyruvic oligophrenia. This metabolic aberration, manifested by the excretion of phenylpyruvic acid, was first described by Fölling in 1934 (1) in 10 feebleminded patients, and cases have subsequently been reported by Penrose $(2)$, Jervis $(3,4)$, and others. The disease is characterized clinically by marked mental deficiency, frequently accompanied by athetosis and other neurological stigmata. Many of the patients are well-developed physically, and even attractive in appearance. Blond hair and complexion and a susceptibility to eczema are frequently observed. The incidence among institutionalized feebleminded individuals of all ages is about 0.8 per cent. On the basis of extensive genetic studies, Jervis (4) confirmed Penrose's opinion (5) that the anomaly is determined by a single autosomal recessive gene.

The quantity of phenylpyruvic acid in the urine varies with the protein intake, but even on a protein-free diet some is always excreted, derived probably from body protein. The excretion of the compound is greatly increased by the administration of phenylalanine, protein (casein), or phenylpyruvic acid, and to a lesser extent by phenyllactic acid, whereas other amino acids, including tyrosine, have no effect on its output. Thus the defect is, apparently, limited to the metabolism of phenylalanine.

\section{REPORT OF CASE ${ }^{1}$}

S. W., a boy aged 25 months, was admitted on November 25,1941 , with the chief complaints of retardation of development and eczema, after a urine specimen had given a positive. qualitative test for phenylpyruvic acid.

${ }^{1} \mathrm{We}$ are grateful to Dr. T. D. Van Orden for the privilege of observing this patient.
The family history was positive for allergic manifestations, including hives in the father, and eczema and asthma in a brother. There was no family history of nervous illness. The only sibling, a brother, had been slow in development, having walked at 2 years of age and talked at 3 , but was described by his pediatrician as entirely normal at his present age of 4 . Tests of the father's, mother's, and brother's urines for phenylpyruvic acid were negative. The pregnancy was complicated by severe nausea and vomiting, and by a small pelvis which necessitated delivery by Caesarian section. The patient had been subject to a severe eczematous eruption since the age of 2 months. Mental retardation had been suspected at 4 months. The infant failed to raise his head until the age of one year, and began to take notice of his surroundings and to recognize his parents at 20 months. His first tooth erupted at 6 months. He sat without support for no more than a few minutes, and did not form words. He did not reach for objects but he seemed to take pleasure in holding a toy when it was placed in his hand.

Convulsions were never observed, but the infant was said to "jump" occasionally, with momentary flexion of the head and extension of all 4 extremities.

Physical examination revealed a large, obese, flabbymuscled, blond boy of 26 months, who could sit unsupported for a few minutes and could maintain himself on his arms and knees in a crouching position. Most of the time he lay quietly on his back. He followed a light or a large object with his eyes, and responded sluggishly to sounds. He had an attractive facies with a smiling. expression. He was goodnatured and contented most of the time, but occasionally cried and sometimes scratched his face, arms, and legs which were the sites of a dry, scaly, patchy, eczematous eruption. The child weighed 14 kilograms, and the body measurement were as follows: head circumference $46 \mathrm{~cm}$., chest $55.5 \mathrm{~cm}$., abdomen $54 \mathrm{~cm}$., stem length $56 \mathrm{~cm}$., total length $89 \mathrm{~cm}$. The head appeared somewhat small in proportion to the body, but was well-formed. The fontanelles were closed. The eyes were blue, the pupils not unusual and the fundi normal. Except for moderately hyperactive deep reflexes the neurological examination was negative, and the remainder of the physical examination revealed no abnormal findings.

Roentgenograms of the skull and wrists were within normal limits. The Kline, Schick, and Mantoux tests were negative, and routine urinalyses and blood count were 
normal. The blood plasma ascorbic acid level which on admission was $0.7 \mathrm{mgm}$. per cent fell to $0.3 \mathrm{mgm}$. per cent after 9 days of low ascorbic acid intake, and rose to $0.6 \mathrm{mgm}$. per cent within 4 hours after an oral test dose of $200 \mathrm{mgm}$. of ascorbic acid.

Psychometric examination by a consultant psychologist confirmed the clinical impression of marked mental retardation.

On admission, the child was given a measured diet, low in ascorbic acid but adequate in thiamin and other vitamins, and calculated to provide 4 grams of protein per kilogram of body weight, daily. The exact amount of nitrogen consumed, including that in added amino acids, is recorded in Table $I$. A description of the chemical methods and a report of the urinary findings follows.

\section{CHEMICAL METHODS}

The method described by Hoag (6) for the quantitative collection of urine in young male infants permitted the collection of 22 12-hour urine specimens without loss. Voidings were timed to the nearest minute, the actual collection periods varying usually between 11 and 13 hours. Results were calculated in terms of 12 -hour periods. The specimens were preserved with toluene.

Total urinary nitrogen was determined by the macroKjeldahl method.

Phenylpyruvic acid may be detected by the development of a transient but characteristic green color upon the addition of 5 per cent ferric chloride to acidified urine. This reaction forms the basis of a quantitative method, worked out by Jervis, Block, Bolling, and Kanze (7) for blood and spinal fluid filtrates, and has been adapted for the determination of the compound in urine.

Phenylalanine was determined by a further modification of the Kapeller-Adler method (8) as recently modified by Block and Bolling (9). The urine was acidified and extracted with ether for 24 hours in a continuous extractor. This procedure removed phenylpyruvic and phenyllactic acids which interfere with the determination of phenylalanine. Tyrosine was removed by treatment with potassium permanganate in the cold, as recommended by Kapeller-Adler ( 8 ).

The optical isomers of phenylalanine were determined by means of the d-amino acid oxidase. The enzyme was extracted with $\mathrm{M} / 60$ sodium pyrophosphate solution at pH 8.0 from acetone-dried sheep kidneys, as described by Negelein and Brömel (10). Their more elaborate procedure ("step 1") was found unnecessary; correction for the error introduced by the small amount of acetone remaining in the kidney extract was made by a suitable blank. This enzyme converts the d-portion of d,1phenylalanine into the corresponding keto acid (phenylpyruvic). The urine to be tested was extracted with ether to remove phenylpyruvic acid and then incubated with the enzyme for 3 hours at $37^{\circ} \mathrm{C}$. Proteins were precipitated with trichloracetic acid, and phenylpyruvic acid determined in the filtrate by the dinitrophenylhydrazone method of Penrose and Quastel (11a), as modified by Sealock (11b). From the amount of phenylpyruvic acid produced, could be calculated the d-phenylalanine in the urine, and 1-phenylalanine could be calculated by difference.

Jervis and his co-workers (7) have reported that phenyllactic acid gives almost as much color in the nitration process of the Kapeller-Adler method as does phenylalanine. Consequently, the method was used for the determination of phenyllactic acid as follows: To the urine was added an equal volume of saturated sodium bisulfite solution. This formed an addition compound with phenylpyruvic acid which was insoluble in ether. The urine-bisulfite mixture was then made just acid to Congo red with sulfuric acid and extracted with ether for 24 hours in a continuous extractor. The ether extract, containing phenyllactic acid, but no phenylalanine or phenylpyruvic acid, was then used for the determination of the former acid by the Kapeller-Adler method. For the purposes of this study, it appears reasonable to assume that the compound determined was actually phenyllactic acid, but complete verification must await isolation of the pure compound from the urine. If error exists, it is presumably in the direction of making the reported amounts of phenyllactic acid too high.

The Millon method as modified by Folin and Ciocalteu (12) was applied to the urine both before and after extraction with ether. Thus the total hydroxyphenyl compounds were divided into ether-soluble and ether-insoluble components.

\section{RESULTS}

\section{Daily excretion of metabolic products}

The results, calculated on the basis of 12-hour periods, are presented in Table I.

Phenylpyruvic acid. The patient always excreted phenylpyruvic acid in amounts varying from 0.45 to 1.03 grams per 24 hours. The gradual rise in excretion during the period of observation may perhaps have been due to his higher than customary intake of protein. In adult patients on a normal diet, Jervis (13) reported a daily output of 1.8 to 2.1 grams of phenylpyruvic acid, and Penrose and Quastel (11a), 1.4 grams.

Phenyllactic acid. The daily output of phenyllactic acid varied from 0.29 to 0.55 gram per 24 hours. Comparable figures for adult patients are not available.

Phenylalanine. The daily urinary output of phenylalanine varied from 0.21 to 0.32 gram. Because a search of the literature revealed no information on the normal urinary excretion of phenylalanine, a series of 11 24-hour urine specimens, from 5 children of comparable age and receiving similar diets, was analyzed. The results are presented in Table II, together with values 
TABLE I

Urinary excretion of protein derivatives in phenylpyruvic oligophrenia

\begin{tabular}{|c|c|c|c|c|c|c|c|c|c|c|c|}
\hline \multirow{3}{*}{ Date } & \multirow{3}{*}{ Weight } & \multicolumn{2}{|c|}{ Nitrogen } & \multicolumn{5}{|c|}{ Phenylalanine derivatives } & \multicolumn{2}{|c|}{ Tyrosine derivatives } & \multirow{3}{*}{ Substance ingested } \\
\hline & & \multirow{2}{*}{ Intake } & \multirow{2}{*}{$\begin{array}{l}\text { Urinary } \\
\text { output }\end{array}$} & \multirow{2}{*}{$\begin{array}{l}\text { Phenyl- } \\
\text { pyruvic } \\
\text { acid }\end{array}$} & \multirow{2}{*}{$\begin{array}{l}\text { Phenyl- } \\
\text { lactic } \\
\text { acid }\end{array}$} & \multicolumn{3}{|c|}{ Phenylalanine } & \multirow{2}{*}{$\begin{array}{c}\text { Ether- } \\
\text { soluble } \\
\text { expressed } \\
\text { as } \\
\text { tyrosine }\end{array}$} & \multirow{2}{*}{$\begin{array}{c}\text { Ether- } \\
\text { insoluble } \\
\text { expressed } \\
\text { as } \\
\text { tyrosine }\end{array}$} & \\
\hline & & & & & & Total & d-form & 1-form & & & \\
\hline & kgm. & $\begin{array}{l}\text { mgm. per } \\
\text { kgm. per }\end{array}$ & $\begin{array}{l}\text { mgm. per } \\
\mathrm{kgm} \text {. per }\end{array}$ & \multicolumn{5}{|c|}{ mgm. per 18 hours } & \multicolumn{2}{|c|}{ mgm. per 18 hours } & grams \\
\hline November 27 to 28 & 14.3 & & $\begin{array}{l}175 \\
200\end{array}$ & $\begin{array}{l}258 \\
195\end{array}$ & $\begin{array}{l}134 \\
159\end{array}$ & $\begin{array}{l}101 \\
107\end{array}$ & 11 & $\begin{array}{l}97 \\
96\end{array}$ & $\begin{array}{r}28 \\
27\end{array}$ & $\begin{array}{l}15 \\
10\end{array}$ & \\
\hline November 28 to 29 & 14.6 & 672 & $\begin{array}{l}200 \\
180\end{array}$ & $\begin{array}{l}260 \\
271\end{array}$ & $\begin{array}{l}245 \\
265\end{array}$ & $\begin{array}{l}124 \\
139\end{array}$ & $\begin{array}{r}19 \\
5\end{array}$ & $\begin{array}{l}105 \\
134\end{array}$ & $\begin{array}{l}28 \\
47\end{array}$ & $\begin{array}{l}20 \\
14\end{array}$ & \\
\hline November 29 to 30 & 14.6 & 579 & $\begin{array}{l}160 \\
188\end{array}$ & $\begin{array}{l}332 \\
328\end{array}$ & $\begin{array}{l}273 \\
233\end{array}$ & $\begin{array}{l}157 \\
146\end{array}$ & $\begin{array}{r}26 \\
20\end{array}$ & $\begin{array}{l}131 \\
126\end{array}$ & $\begin{array}{r}94 \\
120\end{array}$ & $\begin{array}{l}28 \\
30\end{array}$ & 7.3 1-tyrosine \\
\hline November 30 to December 1 & 15.0 & 640 & $\begin{array}{l}200 \\
250\end{array}$ & $\begin{array}{l}454 \\
461\end{array}$ & $\begin{array}{l}276 \\
273\end{array}$ & $\begin{array}{l}168 \\
155\end{array}$ & $\begin{array}{l}29 \\
23\end{array}$ & $\begin{array}{l}139 \\
132\end{array}$ & $\begin{array}{r}78 \\
105\end{array}$ & $\begin{array}{l}38 \\
57\end{array}$ & \\
\hline December 1 to 2 & 14.8 & 730 & $\begin{array}{l}220 \\
191\end{array}$ & $\begin{array}{l}1988 \\
1332\end{array}$ & $\begin{array}{l}566 \\
910\end{array}$ & $\begin{array}{r}1951 \\
686\end{array}$ & $\begin{array}{r}1619 \\
323\end{array}$ & $\begin{array}{l}332 \\
363\end{array}$ & $\begin{array}{r}118 \\
63\end{array}$ & $\begin{array}{l}\mathbf{5 1} \\
\mathbf{3 3}\end{array}$ & 7.4 d,1-phenylalanine \\
\hline December 2 to 3 & 14.8 & 640 & $\begin{array}{l}274 \\
219\end{array}$ & $\begin{array}{r}1294 \\
737\end{array}$ & $\begin{array}{l}366 \\
437\end{array}$ & $\begin{array}{l}367 \\
200\end{array}$ & $\begin{array}{l}66 \\
32\end{array}$ & $\begin{array}{l}301 \\
168\end{array}$ & $\begin{array}{l}77 \\
56\end{array}$ & $\begin{array}{l}38 \\
17\end{array}$ & . \\
\hline December 3 to 4 & 14.8 & 592 & & & & & & & & & \\
\hline December 4 to 5 & 14.7 & 656 & $\begin{array}{l}247 \\
188\end{array}$ & $\begin{array}{l}517 \\
512\end{array}$ & $\begin{array}{l}263 \\
291\end{array}$ & $\begin{array}{l}153 \\
159\end{array}$ & $\begin{array}{l}39 \\
30\end{array}$ & $\begin{array}{l}114 \\
129\end{array}$ & $\begin{array}{l}56 \\
44\end{array}$ & $\begin{array}{l}20 \\
15\end{array}$ & \\
\hline December 5 to 6 & 14.6 & 656 & $\begin{array}{l}209 \\
142\end{array}$ & $\begin{array}{l}508 \\
356\end{array}$ & $\begin{array}{l}233 \\
152\end{array}$ & $\begin{array}{r}179 \\
91\end{array}$ & $\begin{array}{l}35 \\
24\end{array}$ & $\begin{array}{r}144 \\
67\end{array}$ & $\begin{array}{l}52 \\
32\end{array}$ & $\begin{array}{l}17 \\
11\end{array}$ & $\begin{array}{l}0.2 \text { ascorbic acid } \\
0.2 \text { ascorbic acid }\end{array}$ \\
\hline December 6 to 7 & 14.9 & 640 & $\begin{array}{l}193 \\
198\end{array}$ & $\begin{array}{l}446 \\
447\end{array}$ & $\begin{array}{l}199 \\
200\end{array}$ & $\begin{array}{l}163 \\
141\end{array}$ & $\begin{array}{l}18 \\
13\end{array}$ & $\begin{array}{l}145 \\
128\end{array}$ & $\begin{array}{l}37 \\
34\end{array}$ & $\begin{array}{l}13 \\
14\end{array}$ & $\begin{array}{l}0.2 \text { ascorbic acid } \\
0.2 \text { ascorbic acid }\end{array}$ \\
\hline December 7 to 8 & 14.8 & 683 & $\begin{array}{l}184 \\
205\end{array}$ & $\begin{array}{l}2141 \\
1997\end{array}$ & $\begin{array}{l}595 \\
470\end{array}$ & $\begin{array}{r}1388 \\
362\end{array}$ & $\begin{array}{l}844 \\
156\end{array}$ & $\begin{array}{l}544 \\
206\end{array}$ & $\begin{array}{l}54 \\
53\end{array}$ & $\begin{array}{l}14 \\
16\end{array}$ & $\begin{array}{l}0.2 \text { ascorbic acid } \\
7.45 \mathrm{~d}, 1 \text {-phenylalanine } \\
0.2 \text { ascorbic acid }\end{array}$ \\
\hline December 8 to 9 & 14.8 & 736 & $\begin{array}{l}222 \\
212\end{array}$ & $\begin{array}{l}1069 \\
\cdot 666\end{array}$ & $\begin{array}{l}327 \\
240\end{array}$ & $\begin{array}{l}261 \\
190\end{array}$ & $\begin{array}{r}35 \\
9\end{array}$ & $\begin{array}{l}226 \\
181\end{array}$ & $\begin{array}{l}19 \\
25\end{array}$ & $\begin{array}{l}\mathbf{5 3} \\
\mathbf{3 2}\end{array}$ & 0.2 ascorbic acid \\
\hline
\end{tabular}

obtained in previous studies in infants. In no instance did the phenylalanine excretion exceed 53 mgm. per 24 hours ( $4.52 \mathrm{mgm}$. phenylalanine nitrogen), the average being $30 \mathrm{mgm}$. per 24 hours (2.5 mgm. nitrogen) which is less than oneseventh the average amount excreted by our patient. In the normal children, the phenylalanine nitrogen amounted to 0.073 per cent of the total urine nitrogen whereas, in the patient with phenylpyruvic oligophrenia, the phenylalanine nitrogen represented 0.42 per cent of the total nitrogen. From this, it would appear that this patient, in contrast to the patient studied by Jervis (13), excreted phenylalanine in the urine in amounts significantly above normal.

The larger part of excreted phenylalanine was of the natural 1 -form. From 4 to 26 per cent (average 14 per cent) was d-phenylalanine. If this figure is to be considered valid in view of the technical difficulties inherent in the determinations of small amounts of d-phenylalanine, it must be explained on the basis of racemization in the body, inasmuch as phenylalanine in the food is undoubtedly 1-phenylalanine. Such in vivo racemization has been shown to occur in the case of d-phenylaminobutyric acid (du Vigneaud and Irish (14)). Racemization would be consistent with the theory of Jervis and his colleagues (7) that the excess phenylalanine in the blood of phenylpyruvic oligophrenics is formed from phenylpyruvic acid, although Fölling, Closs, and Gamnes (15) maintained that the excess phenyllalanine found in the blood in their cases was all the levo form.

Tyrosine derivatives. The daily excretion of hydroxyphenyl compounds averaged $77 \mathrm{mgm}$. for the ether-soluble and $30 \mathrm{mgm}$. for the etherinsoluble portion. In the 5 normal subjects concerning whom other data are presented in Table II, an average figure for the ether-insoluble fraction was $27 \mathrm{mgm}$. There is, therefore, no evidence of any abnormal excretion of hydroxyphenyl compounds in this case of phenylpyruvic oligophrenia. 
TABLE II

Urinary excretion of phenylalanine and tyrosine by young infants and children compared to that of the patient with phenylpyruvic oligophrenia, per 24 hours

\begin{tabular}{|c|c|c|c|c|c|c|c|}
\hline Subject & Age & Weight & $\begin{array}{l}\text { Protein } \\
\text { intake }\end{array}$ & $\begin{array}{c}\text { Total } \\
\text { nitrogen } \\
\text { in urine }\end{array}$ & $\begin{array}{c}\text { Tyrosine* } \\
\text { nitrogen }\end{array}$ & $\begin{array}{l}\text { Phenyl- } \\
\text { alaninet } \\
\text { nitrogen }\end{array}$ & $\begin{array}{l}\text { Phenylalanine as } \\
\text { per cent of total } \\
\text { nitrogen }\end{array}$ \\
\hline D. S. & $3 \frac{1}{3}$ years & $\begin{array}{l}\mathrm{kgm} . \\
13.0\end{array}$ & $\begin{array}{c}\text { grams per } \\
\text { kgm. } \\
6.8\end{array}$ & $\begin{array}{l}\text { grams } \\
8.43 \\
6.68\end{array}$ & $\begin{array}{l}m g m . \\
3.48 \\
2.89\end{array}$ & $\begin{array}{l}m g m . \\
4.52 \\
3.28\end{array}$ & $\begin{array}{l}0.054 \\
0.049\end{array}$ \\
\hline $\begin{array}{l}\text { P. M. } \\
\text { Tuberculosis }\end{array}$ & $2+$ years & 14.2 & 2.6 & $\begin{array}{l}1.62 \\
2.32 \\
1.69\end{array}$ & $\begin{array}{l}2.25 \\
2.21 \\
2.20\end{array}$ & $\begin{array}{l}2.23 \\
1.78 \\
3.36\end{array}$ & $\begin{array}{l}0.138 \text { (Thymol)\& } \\
0.077 \text { (Thymol) } \\
0.199 \text { (Thy }\end{array}$ \\
\hline $\begin{array}{l}\text { J. L. Tuberculosis, } \\
\text { malnutrition }\end{array}$ & 4 years & 13.4 & $\begin{array}{l}3.5 \\
4.7\end{array}$ & $\begin{array}{l}3.53 \\
5.38\end{array}$ & $\begin{array}{l}1.31 \\
2.50\end{array}$ & $\begin{array}{l}2.09 \\
4.41\end{array}$ & $\begin{array}{l}0.059 \\
0.082\end{array}$ \\
\hline A. $\mathrm{K}$. & $3 \frac{1}{2}$ years & 8.7 & $\begin{array}{l}4.1 \\
2.9\end{array}$ & $\begin{array}{l}2.32 \\
4.47\end{array}$ & $\begin{array}{l}0.60 \\
1.41\end{array}$ & $\begin{array}{l}0.66 \\
1.68\end{array}$ & $\begin{array}{l}0.028 \\
0.038\end{array}$ \\
\hline W. K. ${ }_{\text {Mastoid, post-operative }}$ & 5 years & 17.5 & $\begin{array}{l}4.4 \\
4.0\end{array}$ & $\begin{array}{l}5.77 \\
4.71\end{array}$ & $\begin{array}{l}2.34 \\
1.75\end{array}$ & $\begin{array}{l}2.31 \\
1.64\end{array}$ & $\begin{array}{l}0.040 \\
0.035\end{array}$ \\
\hline $\begin{array}{l}\text { Premature infants } \\
24 \text { days on } 9 \text { infants }\end{array}$ & $\begin{array}{l}8 \text { to } 25 \\
\text { days }\end{array}$ & $\begin{array}{l}1.82 \text { to } \\
3.14\end{array}$ & 6.0 & 0.96 & 1.93 & 2.25 & 0.230 \\
\hline $\begin{array}{l}\text { Full term infants } \\
3 \text { days on } 2 \text { infants }\end{array}$ & $\begin{array}{l}17 \text { to } 21 \\
\text { days }\end{array}$ & $\begin{array}{l}3.53 \text { to } \\
3.88\end{array}$ & 4.5 & 1.66 & 0.88 & 2.55 & 0.150 \\
\hline $\begin{array}{l}\text { S. W. } \\
\begin{array}{c}\text { Phenylpyruvic } \\
\text { oligophrenia }\end{array}\end{array}$ & 2 years & 14.5 & $\begin{array}{l}4.2 \\
4.1\end{array}$ & $\begin{array}{l}5.68 \\
5.78\end{array}$ & $\begin{array}{l}4.10 \\
2.32\end{array}$ & $\begin{array}{l}23.29 \\
25.06\end{array}$ & $\begin{array}{l}0.41 \\
0.43\end{array}$ \\
\hline
\end{tabular}

* One mgm. tyrosine nitrogen is equivalent to $12.93 \mathrm{mgm}$. of the amino acid.

† One mgm. phenylalanine nitrogen is equivalent to $11.79 \mathrm{mgm}$. of the amino acid.

\& Poor specimen - several enureses.

\section{Effect of ingestion of tyrosine}

Seven and three-tenths grams 1-tyrosine $(0.5$ gram per $\mathrm{kgm}$.) was administered by mouth in a single dose without significant effect on the urinary excretion of phenylpyruvic acid or phenylalanine (Table I). The slight increase in tyrosine and its derivatives represented roughly 2 per cent of the amount ingested and is not indicative of any fault in the metabolism of tyrosine. This confirms the results obtained by Jervis (13).

\section{Effect of ingestion of phenylalanine}

The ingestion of 7.4 grams d,1-phenylalanine ( 0.5 gram per $\mathrm{kgm}$.) caused a marked increase in the urinary excretion of phenylpyruvic and phenyllactic acids and phenylalanine. In the first 24 hours, 2.404 grams phenylpyruvic acid, 0.926 gram phenyllactic acid, and 2.313 grams phenylalanine were excreted in excess of the foreperiod levels, thus accounting for approximately 76 per cent of the ingested dose (Table III). Within 48 hours, the extra excretion had amounted to 98 per cent of the ingested dose. ${ }^{2}$

The maximum excretion of phenylpyruvic acid and phenylalanine was reached during the first 12 hours, whereas phenyllactic acid excretion reached its peak during the second 12 hours.

The magnitude of phenylpyruvic acid increase after phenylalanine is comparable to that observed by Penrose and Quastel (11a) who gave 3 grams of phenylalanine to phenylpyruvic oligophrenic adults and obtained an excretion of extra phenylpyruvic acid equivalent to the total phenylalanine fed.

\footnotetext{
2 As was suggested in the description of methods, the values for phenyllactic acid may be too high, both in foreperiods and after amino acid ingestion. Even disregarding entirely this fraction, a minimum of 64 per cent of ingested phenylalanine is accounted for in the first 24 hours by the excretion of phenylalanine and phenylpyruvic acid, and 82 per cent in 48 hours.
} 
TABLE III

Urinary excretion of phenylalanine derivatives after ingestion of $d, l$-phenylalanine

\begin{tabular}{|c|c|c|c|c|c|}
\hline \multirow[t]{2}{*}{. } & \multirow{2}{*}{$\begin{array}{c}\text { Phenyl- } \\
\text { pyruvic } \\
\text { acid }\end{array}$} & \multirow{2}{*}{$\begin{array}{l}\text { Phenyl- } \\
\text { lactic } \\
\text { acid }\end{array}$} & \multicolumn{2}{|c|}{ Phenylalanine } & \multirow{2}{*}{ Tota } \\
\hline & & & d-form & 1-form & \\
\hline
\end{tabular}

INGESTION OF 7.4 GRAMS d,1-PHENYLALANINE

\begin{tabular}{r|c|c|c|c|c}
\hline Foreperiod level-mgm. & 458 & 275 & 26 & 136 & \\
Extra excretion & & & & & \\
First 12 hours-mgm. & 1530 & 291 & 1593 & 196 & \\
Per cent of intake* & 20.7 & 3.9 & 21.5 & 2.6 & 48.7 \\
2nd 12 hours-mgm. & 874 & 635 & 297 & 227 & \\
Per cent of intake & 11.8 & 8.7 & 4.0 & 3.1 & 27.6 \\
3rd 12 hours-mgm. & 836 & 91 & 40 & 165 & \\
Per cent of intake & 11.3 & 1.2 & 0.5 & 2.2 & 15.2 \\
4th 12 hours-mgm. & 279 & 162 & 6 & 32 & \\
Per cent of intake & 3.8 & 2.2 & 0.1 & 0.4 & 6.5 \\
& & & & & 98.0 \\
& & & & & \\
\hline
\end{tabular}

INGESTION OF 7.45 GRAMS d,1-PHENYLALANINE $\dagger$

\begin{tabular}{r|c|c|c|c|c}
\hline Foreperiod level-mgm. & 447 & 200 & 16 & 137 & \\
Extra excretion & & & & & \\
First 12 hours-mgm. & 1694 & 395 & 828 & 407 & \\
Per cent of intake & 22.7 & 5.3 & 11.1 & 5.5 & 44.6 \\
2nd 12 hours-mgm. & 1550 & 270 & 140 & 69 & \\
Per cent of intake & 20.8 & 3.6 & 1.9 & 0.9 & 27.2 \\
3rd 12 hours-mgm. & 622 & 127 & 19 & 89 & \\
Per cent of intake & 8.3 & 1.7 & 0.3 & 1.2 & 11.5 \\
4th 12 hours-mgm. & 219 & 40 & -7 & 44 & \\
Per cent of intake & 2.9 & 0.5 & -0.1 & 0.6 & 3.9 \\
& & & & & 87.2 \\
\hline
\end{tabular}

* The molecular weights of these three compounds are so nearly identical that calculations of percentages or sums of percentages are the same whether reported "as phenylpyruvic acid," "as phenyllactic acid" or "as phenylalanine."

$\dagger$ Diet unchanged except for ingestion of 0.4 gram ascorbic acid daily.

The high excretion of phenylalanine, both before and particularly after the ingestion of this substance, was in contrast to the observation of Jervis (13) who found none at all in the urine of a phenylpyruvic oligophrenic, even after administering phenylalanine by mouth. Fölling, Closs, and Gamnes (15), using a qualitative method, reported that an increased excretion of phenylalanine followed the oral or intravenous administration of d-phenylalanine to their human subjects.
It is interesting to note that only about 6 per .cent of the ingested d,1-phenylalanine was excreted as the 1-isomer, whereas 13 to 25 per cent of it was excreted as d-phenylalanine. Presumably the body excreted more of the unnatural enantiomorph which is less readily metabolized.

\section{Effect of ascorbic acid}

Because vitamin $C$ has been shown to prevent or relieve a defect in the metabolism of tyrosine and phenylalanine exhibited by premature infants (16), it was tested in this case of phenylpyruvic oligophrenia (Tables I and III). It was completely without effect in relieving the spontaneous phenylketonuria and did not prevent the increased excretion of the metabolic products of phenylalanine after the administration of the amino acid. It is unlikely that the small differences in the rate and pattern of excretion of the derivatives in the two sets of observations following phenylalanine ingestion are attributable to ingested ascorbic acid. Jervis (17) found similar results in his patients.

\section{DISCUSSION}

The path of normal metabolism of phenylalanine is still a matter of speculation. Presumably, it is first deaminized to form the -keto acid, phenylpyruvic acid, which may then be completely oxidized. There is, however, evidence that at least some phenylalanine may be converted in the body to tyrosine or its metabolic products, p-hydroxyphenylpyruvic and p-hydroxyphenyllactic acids (18). In phenylpyruvic oligophrenia, there is apparently no impairment in the metabolism of tyrosine. Even after the administration of tyrosine or phenylalanine there is no significant increase in urinary excretion of substances giving the Millon reaction. This finding, taken in conjunction with the fact that ingested phenylalanine can be accounted for almost quantitatively as excess phenylpyruvic and phenyllactic acids and phenylalanine, would indicate that phenylpyruvic oligophrenics do not metabolize phenylalanine by way of tyrosine. It is interesting to speculate whether tyrosine, which is not considered an essential amino acid in normal individuals, may be essential in these cases. If patients with phenylpyruvic oligophrenia are unable to form tyrosine from phenylalanine or its metabolic products, then 
they must be dependent on a dietary intake of tyrosine for their metabolic needs of this amino acid.

Undoubtedly, phenylalanine is deaminized to phenylpyruvic acid, but the mechanism and site of this deamination are still uncertain. If it takes place chiefly in the liver, one would expect to find phenylpyruvic acid in the blood in the process of transportation to the kidneys. Both Fölling, Closs, and Gamnes (15) and Jervis and his colleagues (7) were unable to find significant amounts of phenylpyruvic acid in the blood of their patients, but they did find abnormally large amounts of phenylalanine in the blood. Jervis concluded that the essential defect of the subjects is an inability to dispose of phenylalanine at a normal rate rather than a failure to break down phenylpyruvic acid, as had been previously assumed. The presence of phenylpyruvic acid in the urine he considered to be an incidental phenomenon, resulting from the deamination of a portion of the blood phenylalanine by kidney tissue.

The excretion by our subject; S. W., of large amounts of phenylalanine after ingestion of this substance may have been due to the size of the dose given ( 7.4 grams, 0.5 gram per $\mathrm{kgm}$. of body weight), which was much greater than that which Jervis (13) administered to his patient. The amounts of phenylalanine in the urine of S. W. were of the same order of magnitude as those found in normal infants given comparable doses (18). The latter, however, never exhibited the most striking metabolic characteristic of the phenylpyruvic oligophrenic, namely, the excretion of significant amounts of phenylpyruvic acid, and they did, in the absence of vitamin $C$, show evidence of conversion of phenylalanine to tyrosine which was not observed in the oligophrenic subject.

The clinical value of the qualitative test for phenylpyruvic acid in the urine of infants suspected of mental retardation should be emphasized. The test should be applied especially in those retarded children who are blond in coloring, and whose mental deficiency is suspected on the basis of slowness in acquiring behavior patterns and yet seems to be belied by an attractive facial appearance. The presence of eczema, of a family his- tory positive for mental deficiency, or of neurological manifestations characteristic of extrapyramidal tract involvement, should also lead to a suspicion of this disease, though their absence does not rule it out.

\section{SUMMARY}

1. Studies were carried out on the metabolism of phenylalanine and tyrosine in a patient with phenylpyruvic oligophrenia.

2. The patient always excreted phenylpyruvic acid in the urine in amounts varying from 0.45 to 1.03 grams per 24 hours. The daily excretion of phenyllactic acid varied from 0.29 to 0.55 gram and of phenylalanine from 0.21 to 0.32 gram per 24 hours.

3. The administration of d,1-phenylalanine $(0.5$ gram per $\mathrm{kgm}$.) resulted in a prompt rise in the excretion of phenylpyruvic and phenyllactic acids and phenylalanine. Within 24 hours after feeding, 76 per cent of it had been excreted; 32 per cent as extra phenylpyruvic acid, 13 per cent as phenyllactic acid, and 31 per cent as extra phenylalanine, about three quarters of the latter being $d$ phenylalanine and the remainder the 1 -isomer. Within 48 hours, the extra excretion had amounted to 98 per cent of the ingested dose.

4. The administration of 1-tyrosine in similar dosage ( 0.5 gram per $\mathrm{kgm}$.) had no significant effect on the excretion of phenylpyruvic acid, nor was there any evidence of an abnormality in the metabolism of tyrosine.

5. The administration of large doses of ascorbic acid ( 0.4 gram per day) had no effect, either on the spontaneous excretion of phenylpyruvic acid or on the increased excretion of metabolic products following the ingestion of phenylalanine.

6. The absence in the urine of significant amounts of hydroxyphenyl compounds in this patient, spontaneously and even after the ingestion of phenylalanine, suggests that the conversion in vivo of phenylalanine to tyrosine, previously shown to take place in the normal organism, is deficient in patients with phenylpyruvic oligophrenia. This finding is consistent with the thesis advanced by Jervis and his coworkers (7) that in this disease the primary metabolic defect is an inability to handle phenylalanine. 


\section{BIBLIOGRAPHY}

1. Fölling, A., Ueber Ausscheidung von Phenylbrenztraubensäure in den Harn als Stoff wechselanomalie in Verbindung mit Imbezillität. Ztschr. f. physiol. Chem., 1934, 227, 169.

2. Penrose, L. S., Two cases of phenylpyruvic amentia. Lancet, 1935, 1, 23.

3. Jervis, G. A., Phenylpyruvic oligophrenia. Introductory study of fifty cases of mental deficiency associated with excretion of phenylpyruvic acid. Arch. Neurol. and Psychiat., 1937, 38, 944.

4. Jervis, G. A., The genetics of phenylpyruvic oligophrenia. J. Ment. Sc., 1939, 85, 719.

5. Penrose, L. S., Inheritance of phenylpyruvic amentia (phenylketonuria). Lancet, 1935, 2, 192.

6. Hoag, L. A., Apparatus for quantitative collection of urine and of stools in male infants. Am. J. Dis. Child., 1932, 44, 770.

7. Jervis, G. A., Block, R. J., Bolling, D., and Kanze, E., Chemical and metabolic studies on phenylalanine. II. The phenylalanine content of the blood and spinal fluid in phenylpyruvic oligophrenia. J. Biol. Chem., 1940, 134, 105.

8. Kapeller-Adler, $R$., Ueber eine neue Reaktion zur qualitativen und quantitativen Bestimmung des Phenylalanins. Biochem. Ztschr., 1932, 252, 185.

9. Block, R. J., and Bolling, D., Chemical and metabolic studies on phenylalanine. I. The nitration of phenylalanine. J. Biol. Chem., 1939, 129, 1.

10. Negelein, E., and Brömel, H., Protein der d-Aminosäureoxydase. Biochem. Ztschr., 1939, 300, 225.

11a. Penrose, L., and Quastel, J. H., Metabolic studies in phenylketonuria. Biochem. J., 1937, 31, 266.

b. Sealock, R. R., The determination of amino acids of the dextro or unnatural configuration. Science, 1941, 94, 73.
12. Folin, O., and Ciocalteu, V., On tyrosine and tryptophane determinations in proteins. J. Biol. Chem., 1927, 73, 627.

13. Jervis, G. A., Metabolic investigations on a case of phenylpyruvic oligophrenia. J. Biol. Chem., 1938, 126, 305.

14. du Vigneaud, V., and Irish, O. J., The rôle of the acetyl derivative as an intermediary stage in the biological synthesis of amino acids from keto acids. J. Biol. Chem., 1938, 122, 349.

15. Fölling, A., Closs, K., and Gamnes, T., Vorläufige Schlussfolgerungen aus Belastungsversuchen mit Phenylalanin an Menschen und Tieren. Ztschr. f. physiol. Chem., 1938, 256, 1.

16a. Levine, S. Z., Marples, E., and Gordon, H. H., A defect in the metabolism of aromatic amino acids in premature infants. The role of vitamin C. Science, 1939, 90, 620.

b. Levine, S. Z., Marples, E., and Gordon, H. H., A defect in the metabolism of tyrosine and phenylalanine in premature infants. I. Identification and assay of intermediary products. J. Clin. Invest., 1941, 20, 199.

c. Levine, S. Z., Gordon, H. H., and Marples, E., A defect in the metabolism of tyrosine and phenylalanine in premature infants. II. Spontaneous occurrence and eradication by vitamin C. J. Clin. Invest., 1941, 20, 209.

17. Jervis, G. A., Personal communication.

18. Levine, S. Z., Marples, E., and Dann, M., A defect in the metabolism of tyrosine and phenylalanine in premature infants. III. Demonstration of the irreversible conversion of phenylalanine to tyrosine in the human organism. In preparation. 